\title{
Images of Thai Women in Magazines for Older Adults
}

\author{
Permtip Buaphet (เพิ่มทิพย์ บัวเพ็ชร์) \\ Lecturer, Bachelor of Arts Program in Language and Culture, \\ Faculty of Arts, Chulalongkorn University, Thailand \\ permtip.b@chula.ac.th
}

\begin{abstract}
This research on the images of Thai women in a magazine for older adults aims to analyze the structure and components of interview columns and examines the linguistic strategies used to present images of Thai women within the context of a magazine for older adults by associating textual analysis with visual methodology. The data collection in this research was grounded on $O$-lunla magazine, a magazine targeting people in their 6os and older. Twenty-two interview columns from ten magazine issues from January 2017 to October 2017 were included. The study discloses how this magazine for older adults defines the meaning of ageing and the role of the magazine in passing particular notions about desirable ageing and images of older women in Thai society through the use of linguistic strategies, as well as emphasizing the concepts of desirable ageing for women. The results with regard to the content reveal that the meanings of ageing and the images of Thai women in their older age in this magazine for older adults are formed in a positive way. That is to say, older women are depicted as archetypes of a pleasant life in terms of happiness, work and health.
\end{abstract}

\section{Keywords}

ageing - image - Thai women - magazines for seniors 
บทคัดย่อ
ภาพลักษณ์ผู้หญิงไทยในนิตยสารสำหรับผู้สูงอายุ

งานวิจัยเรื่อง ภาพลักษณ์ผู้หญิงไทยในนิตยสารสำหรับผู้สูงอายุ มุ่งศึกษาวิเคราะห์โครงสร้างและองค์ประกอบของบทสัมภาษณ์ และกลวิธีทางภาษาที่ใช้ในการนำเสนอภาพลักษณ์ผู้หญิงไทยในบริบทของนิตยสารสำหรับผู้สูงอายุโดยใช้วิธีการวิเคราะห์ตัว บทและภาพ ข้อมูลได้มาจากนิตยสารโอ-ลั้น-ลา $(O-l u n l a)$ จำนวน 10 ฉบับ และ บทสัมภาษณ์จำนวนทั้งสิ้น 22 เรื่อง ตั้งแต่ เดือนมกราคม 2560 ถึงเดือนตุลาคม 2560 นิตยสารเหล่านี้มีกลุ่มผู้อ่านเป็นผู้สูงวัยอายุตั้งแต่ 60 ปี ขึ้นไป ผลการศึกษา แสดงให้เห็นถึงวิธีการที่นิตยสารสำหรับผู้สูงอายุในกลุ่มตัวอย่างกำหนดความหมายของความสูงวัย และบทบาทของนิตยสาร สำหรับผู้สูงอายุในการส่งผ่านความคิดบางประการเกี่ยวกับความชราและภาพลักษณ์ผู้หญิงสูงอายุอันพึงปรารถนาในสังคม ไทยผ่านการใช้กลวิธีทางภาษาเช่นเดียวกับการเน้นย้ำความคิดเรื่องความสูงอายุที่พึงประสงค์สำหรับผู้หญิง ผลการศึกษาใน ด้านเนื้อหาชี้ให้เห็นว่าความหมายของความชราและภาพลักษณ์ผู้หญิงสูงอายุชาวไทยในนิตยสารสำหรับผู้สูงอายุได้รับการนำ เสนอในแง่บวก กล่าวคือ ผู้หญิงสูงวัยถูกให้ความหมายในฐานะการเป็นแม่แบบของการมีชีวิตที่น่าพึงพอใจในด้านความสุข การ ทำงาน และสุขภาพ

\section{Introduction $^{1}$}

According to Jitapunkul and Chayovan (2001: 2), "Thailand is currently experiencing among the most rapid rates of population ageing in the developing world." The National Committee for the Elderly (2014: 6) has suggested that Thailand will be an "ageing society when the population older than age 60 years and over has reached 20 percent in 2021 or in the next four years." Moreover, the amount of future population ageing, as Knodel et al. (2015:2) has stated, will increase to "over 30 percent of the population or over twenty million older adults by 2035." Population ageing is a challenge to the economic and social development of Thailand since it will affect the number of working-age people in Thailand in the future. Furthermore, the cost of healthcare for older people will increase. Families and government, therefore, will have to undertake this burden. A Thai elderly health survey in 2013 revealed that two percent of the elderly were disabled and unable to help themselves. Additionally, "fifty-eight percent of them had movement disorders" (see also The National Committee for the Elderly 2014:8). These problems of older people may cause the perception of the ageing population as a "burden" and create negative attitudes towards older people.

Women are more likely to constitute the majority of the aged population because of gender differences in longevity. That is to say, in the year

1 (This research was supported by a research grant from the Faculty of Arts Research Fund, Chulalongkorn University). 
2040, as The National Committee for the Elderly (2014: 28) has pointed out, "the sex ratio of the elderly population in Thailand will be 91.6 males per 100 females." According to the United Nations (UN) 2015, both in 2025 and 2050, 54 percent of the total Thai population at age 60 and older will be represented by women. This predominance of women, as Knodel et al. (2015:19) has proposed, is regarded as the "feminization of ageing." This trend will also be the case in Thailand, where older women will be the majority of the aged population in the near future. One way to understand how Thai women are ageing in the trend of women outliving men is to examine the concept of ageism since the state of the aged is not fixed to be the same in all places and at all times.

Ageism, as proposed by Butler (1969: 243), is the "systematic stereotyping of and discrimination against people because they are old." Oldness, in this sense, is connected to particular stereotypes and prejudices. Butler's claim conforms to the work of Bytheway (1995), Calasanti and Slevin (2001), and Holstein (2001), who have revealed discrimination against older people by showing that ageing is thought to involve sexlessness, unhealthiness, physical unattractiveness and social unacceptance. In a study on ageing in 1960, Burgess (1960: 20) stated that "a woman was more likely to be seen to have a much smoother shift into later life by reason of maintaining the role and satisfaction of homemaker." This emblem of the "satisfaction of homemaker" became a distinguishing aspect of the discourse on womanhood from the 1950 s to the 1960s. In The Feminine Mystique (1963), the conventional idea of women's lives depicted in women' magazines as housewives and mothers was confronted by Friedan. Her work provoked debate in regard to women's roles in particular. De Beauvoir (1970) provided greater understanding of the perception of an ageing population in The Coming of Age by employing empirical and philosophical methods to tackle the dilemma of the old age and sexual difference. She indicated that the elderly in 70's society were neglected and perceived as marginal. These negative stereotypes of ageing, after almost 50 years, are still the case nowadays in Thailand, where the depiction of older people has been negative as evidenced in a study entitled The Construction of the Elderly Representations (2014). In this research article, Supawan and Kanganakitsakul (2014: 94) demonstrate that the institutions in Thai society, such as social, political, educational and economic institutions, represent old people in a negative way. Individuals' abilities are seen to be limited and they are excluded from society. One question for me was the extent to which this was reproduced in the portrayals of elderly women in a magazine for older adults. 
Studies of the images of older people in Western countries have extended to covering the images of ageing in the mass media (e.g. Kessler, Rakoczy, and Staudinger 2004; Zhang et al. 2006; Lee, Carpenter and Meyers 2007). Most research focuses on public images of ageing, as Lumme-Sandt (2011: 45) has argued, "have an influence on social attitudes toward old people." One common belief, according to Buaphet (2014:112), seems to be that "ageing is linked to negative issues and this is the primary theme for the portrayal of old age in different sources, especially in the popular media." The problems concerning the elderly as mentioned above have led to research on older age, with a tendency for studies to be focused on health problems and health concerns regarding ageing in Thai society in particular. Examples include: Falls in Thai Older Persons (Junwang 2015), Factors Associated with Knowledge of Caregivers among Elderly Thais (Saengchan 2014), Needs for Assistance of the Thai Elderly Living Alone (Kaikeaw 2014), The Proposed Policy on Preparation for the Ageing Thai Population (Amsuk 2013) Factors Influencing Psychological Health of Thai Elderly Population (Sanitya 2012), Factors Affecting Healthcare Expenditure of the Thai Elderly (Potharin 2011), and Demand for Long-Term Care Services of the Elderly in Bangkok Metropolitan (Suwannarada et al. 2010). These studies provide additional support for the idea of ageing adults in the Thai context as unhealthy, dependent and disadvantageous.

When the negative portrayal of women as inferior to men was widely recognized, researchers emerged to examine images of women from different perspectives. The study, The Identity of Competent Women in Women's Magazines Between 1997-2002 by Chaiyasin (2004), for example, revealed the positive identities of women in terms of gender culture. That is to say, women and men play equal roles in both domestic and public spheres. However, this research contradicts Maison's (2001) The Power of Women's Negotiation through Body Presentation in Thai Magazines and Nirannoot's (2003) The Perpetuation of Patriarchy through Women's Magazines, which insist that women are misrepresented in Thai women's magazines as sex objects for public pleasure and are inferior to men. After reviewing all the above related research, these different findings led to the unresolved issue of the portrayal of women in Thai magazines for older adults from a gender perspective by taking into account the impact of cultural expectations of ageing women. A greater focus was placed on the portrayals of Thai woman in magazines for older people; hence, how are ageing and womanhood constructed in magazines for older adults? This is the fundamental question of this research. In the next section, information on the magazine and samples under analysis will be discussed. 
Ten issues of O-lunla magazine during the period from January 2017 to October 2017 were the primary source for data collection. This Thai magazine was first launched in October, 2016. It was selected for three particular reasons: firstly, the magazine is aimed at people aged over sixty years, presented by its use of the slogan "for older adults' pleasure: Did you embrace your parents today?" on the front cover. This magazine is thus relevant to my research since I shall analyze the depiction of Thai women in the magazine for older adults published in the Thai cultural context. Secondly, unlike any other magazines for older adults in Thailand, O-lunla is a free magazine, placed at well-known hospitals in Thailand such as BNH Hospital, Phayathai Hospital, Vichaiyut Hospital, Siriraj Piyamaharajkarun Hospital, Saint Louis Hospital, Chaophya Hospital, etc. Therefore, $O$-lunla magazine was launched for a particular purpose in terms of its readership and content. Thirdly, there used to be a magazine for older adults in Thailand named Young@Heart by Kwankao publisher in 2011. Its price was 70 baht per issue. The magazine included useful articles such as health, travel and advice related to older adults who were 50 years old and above. The magazine aimed to help the elderly prepare themselves for upcoming retirement age. However, only five issues of Young@Heart were released. The magazine is no longer published due to economic reasons. Although there are other magazines related to the elderly in terms of their contents in the Thai cultural context such as Health Today, Women's Health, Cheewajit, Secret, etc., these magazines are not aimed directly at older people. This is evident in their use of the slogans: "empowering you to healthy living", "beautiful inside out", "inspiration for active people", and "happiness and success in life" respectively. Therefore, $O$-lunla magazine has been selected because it most closely represents a magazine for older adults in the Thai context.

Based on the interview columns that the magazine included, the Cover story and O-happy columns were selected respectively. The Cover story column contains the life stories of the people that are displayed on the front cover. The women in the Cover story column are more likely to be celebrities. The stories in the O-Happy column, on the other hand, describe ordinary women's reallife experiences and particular topics. The female interviewees in the O-happy column are typically ordinary women. Examining the interview columns by and about both female celebrities and ordinary women allows for an understanding of how the images of elderly women are constructed in the magazine for older people. Elderly women are the center of this study: older men are not included. The aim of the study is to interpret the cultural meanings intrinsic in 
the notion of ageing in Thai society since older women, as claimed by Russell (1987: 127), "experience a range of social and cultural disadvantages" or "the double standard of ageing" (see also Sontag 1972; Bell 1976).

The two columns, Cover story and O-happy, are narrated by both columnists and interviewees in terms of questions and answers based upon themes. This is made evident by the columnist's name appearing in the interview column: "Cover story, Text: Nunmanut" (May 2017, p. 14). Having the columnist's name at the top of the page before the interviewee's name at the beginning of a story indicates the contribution from the columnist to the story. More specifically, the particular notions are constructed through questions asked by the columnist in the interview column. The interview columns by and about both celebrities and ordinary women were selected since examining the language used by these women, as well as by the columnists, can disclose the particular ideology and images of women embedded in the interview columns. The study of the depiction of women in the magazine for older adults, therefore, may create an understanding of how the magazine influences the way in which women age. Moreover, it may construct positive viewpoints of and decrease negative attitudes towards the elderly and heighten social awareness of the value of Thai elderly women.

Theoretical Frameworks and Analytical Approaches

The analysis of the depiction of elderly women and ageing in the magazine in this study is premised upon two interdisciplinary theoretical areas, women's studies and ageing studies. Feminist approaches can be used to examine the construction of ageing since ageing and ageism, according to Marshall (2006: vii) are "important feminist issues." "Images of ageism," as defined by Humm (1995: 6), "reinforce internalized attitudes of subordination and maintain practices of inequality which are mainly experienced by older women". Ageing, in my research, is viewed as the social construction of the concept of old age, which is the result of textual and visual discourses. In order to explore contemporary notions of ageing in the magazine for older adults, I center on what is valued about ageing and how age as a principle of self-identity and womanhood might be portrayed in the magazine.

There are three main approaches used in this qualitative study: content analysis, discourse analysis and visual methodology. The content analysis involved frequency counting and collation, especially of keywords that define the concept of "ageing" and the images that represent "elderly women," followed by the interpretation of the fundamental texts. The lists of stories were categorized under meta-themes in order to pursue the thematic analysis. The theme 
selection was directed by the main titles and data employed. This is consistent with the method of analyzing the frequency of certain images.

Next, discourse analysis was applied to examine the meaning-making and linguistic strategies embedded in each text which shaped how ageing and older women were understood and how these were carried out in the texts. Discourse, according to Nead (1988: 4), is "a particular form of language with its own rules and conventions and the institutions within which the discourse is produced and circulated," and the focus is thus set on the vocabulary used to reveal notions of ageing and womanhood in context. Such vocabulary can frame the users' thoughts and beliefs, explicitly when there are repeatedlyused words. To put it another way, discourse analysis, as noted by Humm (1995: 67), can reveal "how dominant social discourses, or practices, misshape women's identities and become the truth." One question one might want to ask is to what extent is this still the case in discourses of femininity in ageing magazines and if it is, what is the type of misrepresentation now?

Since discourse analysis, as pointed out by Fairclough (2010: 230), is "concerned with various semiotic modalities of which language is only one", visual methodologies are thus engaged to analyze the photos presented as part of the interview columns. Visuality, according to Gillian Rose (2014: 191), is "considered as a sort of discourse since a specific visuality will make certain things visible in particular ways, and other things unseeable." Visual methodologies, in this sense, were used to interpret the meanings of the representational and nonrepresentational images in Thai magazines for older adults. A critical visual methodology, as proposed by Rose (2014: 19), must be concerned with the social effects of an image, which are made at three sites: "the site of production, which is where an image is made; the site of the image itself, which is its visual content, and the site of audiencing, where the image is seen by various audiences." These three sites were explored in order to explain the interpretation of visual images and how the images affect the making of meaning in the interview columns.

The Ideas of Ageing in Interview Columns in the Magazine for Older Adults

The focus in this section is the ideas of ageing that are expressed in the interview columns in the magazine for older adults. The interview columns in the magazine for older adults in my sample consist of three parts: introduction, body and ending. The introduction, in the first section, usually begins with photos of the interviewees and then come the headings or the story titles of the interview columns, which also contain the female interviewees' names. 
The story titles and women's names ordinarily appear in large colorful letters in order to draw attention, as is evidenced by the large font size. Besides the names of the interviewees in the introduction, the magazine provides certain themes for them to tell their stories. The story titles can be categorized into three groups: 1. happiness, 2. work, and 3. health. These titles are approximately one to two sentences in length, indicating a prominent life.

The story titles in connection with happiness are commonly demonstrated by encouraging a set of career values that emphasize the abilities and skills in one's work life, for example, 'Music for a happy heart: granny Lin-Malinda Hermann, a 67-year-old singer at Hey! Mom Bar, Watcharapol Junction' ( $O$ lunla, January 2017: 17) and 'Associate Professor Promjit Sornlum: Herb and Happiness' (O-lunla, April 2017: 20). More specifically, the happiness titles in my sample are always presented in relation to work. This implies that keeping on working into old age can bring happiness to one's life. When it comes to work, there are only two types of stories: stories about current occupations and about jobs after retirement. Examples are: 'Valuable expertise@Centara' (O-lunla, May 2017: 14) and 'Yoga, body, heart, and a new job after retirement' (O-lunla, July 2017: 9). Lastly, the story titles also reveal a significant attribute in a woman's life - good health. The magazine portrays the role of old women in a particular way. That is to say, older women have an influence on inspiring other women to follow their dreams regardless of age. This is associated with physical health in the sense that staying healthy is goal-directed behavior which leads to happiness and the achievement of the dreams in old age, as displayed in the title: 'Do what you like when you are still strong: aunty Peaw Kanjana Panthutaecha, the owner of 'pabackpack' Facebook page, and a tour guide' (O-lunla, January 2017: 14). The main titles in the introduction section imply three main concepts: happiness, work and health as shown in Table 1.

TABLE 1 The significant attributes of old women covered in the story titles in the magazine for older adults

\begin{tabular}{|c|c|c|c|}
\hline \multirow{2}{*}{$\begin{array}{l}\text { Themes in the } \\
\text { Story Titles }\end{array}$} & Magazine & Solumns & \multirow{2}{*}{$\begin{array}{l}\text { Numbers of } \\
\text { Stories }\end{array}$} \\
\hline & Cover Story & O-Нарру & \\
\hline
\end{tabular}

\begin{tabular}{lrrr}
\hline Happiness & 7 & 4 & 11 \\
Work & 6 & 2 & 8 \\
Health & 1 & 2 & 3 \\
Total & 14 & 8 & 22 \\
\hline
\end{tabular}


Table 1 shows that there were 22 stories in total in my sample. There were eleven, eight and three story titles concentrating on happiness, work and health respectively. Story titles associated with happiness in the introduction were most commonly found in the magazine. However, there were only three main titles related to health compared with eleven story titles about happiness. The titles in relation to happiness were thus almost four times more common in the magazine in my sample. This indicates that happiness, compared to work and health, is regarded as the most important attribute in a woman's life, especially in old age.

The portrayals of women in connection with happiness are reinforced by photos in the introduction in both the Cover story and O-happy columns. These photos are displayed as large-sized portraits with women's faces looking directly at reader in still postures, implying a staged portrait that emphasizes the significance of the interviewees. Furthermore, they usually have a splendid setting and the women are always smiling at the camera. There is usually only one large photo in the introduction. The large photos are portraits, sometimes full-length or occasionally semi-portraits.

In the introductory section, there is always a short paragraph following the photo and the story title written by the columnist. This part of the introduction has approximately $3-5$ sentences or 1 paragraph. The columnist provides the woman's personal details, such as name, age, occupation and positive character traits in order to introduce her; for instance, '65 years old, she is still smart, active, and energetic, but while working, she can concentrate on her task without being distracted for a couple of hours or more' (O-lunla, June 2017, p. 15), and ' 71 years old, Ajarn Promjit Sornlum, a director of Sireeruckhachati Nature Learning Park, Mahidol University, is still healthy, active and has a very good memory. She is able to remember many kinds of herb. During the interview, she answered the questions with shiny eyes...' (O-lunla, April 2017, p. 27). More specifically, both the texts and photos in the introductory section describe older women in a positive way with pleasant character traits such as a youthful appearance, fewer skin wrinkles, dyed hair and slim bodies. The images of women with an ageless look in the magazine denigrates the natural signs of growing older and marginalizes other ordinary older women by individualizing these older women in the interview columns and differentiating them from other elderly women.

The next component in the interview column is the body, which is the longest section compared with the introduction and ending in the interview column. The overall content of a given story is arranged by combining the columnist's questions, the interviewee's answers, and the photos. There are approximately 5 to 10 questions in each interview column and each story is 
approximately 1 to 4 pages in length. The main narrative itself is distinguished from the introduction by different forms of pronoun. The content section begins when the first-person pronoun "I" is used to refer to the person telling her story. The text thus uses a third person narrator to introduce a story but then switches to first-person narration for the main story. This conveys a sense of immediacy, giving the impression of the interviewee talking directly to the reader.

The questions in this part are linked to the story title and are set in accordance with the story titles in the introductory section under the three themes, happiness, work and health. It is noticeable that the questions in the interview columns frame the notion of work as happiness in a woman's life, as made evident by questions such as 'what is your happiness at work?' (O-lunla, April 2017, p. 29) and 'how did you find out that writing a book is your happiness?' $(O-$ lunla, July 2017, p. 24). Furthermore, the questions in the body section highlight the value of working after retirement age. Work, in this sense, is considered a woman's resource for happiness. Examples included 'what is the main reason for you to work after retirement?' (O-lunla, April 2017, p. 27), 'how about working at 71 years old?' (O-lunla, April 2017, p. 30), and 'what did your family think when you returned to work after retirement?' (O-lunla, May 2017, p. 16). Even the questions with regard to health appear with reference to work life such as 'How do you take care of yourself and boost your energy at work?' (O-lunla, February 2017, p. 22) and 'How does old age affect your writing?' (O-lunla, July 2017, p. 25). These questions in the content of the interview columns suggest the notion of what is valued about elderly women in Thai society, as displayed in the magazine I examined.

Furthermore, the content in the body of the interview columns indicates that ageing in the magazine for older adults is presented through personification in a positive way. Personification, as noted by Leigh (1994: 19), is "ascribing inanimate objects or abstractions with human qualities or abilities." Personification thus enables us to understand ageing. Personification is employed to address the positive attributes of ageing as seen in the following example: 'At age 60 , her movement may not be active as it used to be. However, her intuitiveness has speeded up' (O-lunla, October 2017, p. 13). Although intuitiveness is abstract, it is personified since it can be active or inactive. Intuitiveness, in this sense, is used to express the woman's positive attribute which is different from other older people. In other words, the magazine studied implies that ageing has undesirable traits, such as the decline of physical movement but that creative thinking is usual among persons aged 60 and older. However, this is not the case for this woman displayed in the magazine since she is able to cope with the undesirable characteristics of ageing such as inactiveness, brittleness, etc. 
The last component of the interview columns is the ending. There were four types of the endings for the interview columns in my sample: 1 . further information, 2. tips and suggestions, 3. advertising a woman's business, and 4. rhetorical questions. Further information is provided at the bottom of the page in order to ask for the readers' cooperation. The main purpose of further information is not only to transfer general information to readers but also to help other aged people in society. A typical example is the following:

'Before leaving, she asked O-Lunla to inform readers that Suandok Hospital Foundation is raising funds to build a Long-term Care Centre for dependent older people. Please donate at Suandok Hospital Foundation tel. 053 - 947400, fax. $053-947888$ or transfer money directly to the Suandok Hospital Foundation bank account: Krungthai Bank, Suthep Rd., Branch, account number 521-052252-0, Bangkok Bank Public Company Limited, Faculty of Associated Medical Sciences Chiang Mai branch, account number 968-0-02053-5, Kasikorn Bank, Suthep rd. branch, account number 471-2-33333-8, The Siam Commercial Bank, Faculty of Medicine branch, account number 566-404844-o' (O-lunla, March 2017, p. 12).

Particular concerns such as healthcare and a given health issue were usually presented as ending a story, with tips and suggestions or additional knowledge. Readers were thus encouraged to learn from the story of other women's experience. These women, in this sense, were portrayed as specialists and experts in particular fields. For instance, one story ended with the following advice from a woman:

'Way of living: older people or retired persons may have a lot of time but their health is declining. The way to avoid disease and stay young is to have concerns about food. Eating is choosing the proper food and right medicine that help prevent disease. If you come to Sireeruckhachati Nature Learning Park, you will learn how to consume herbs properly. Eat food as medicine, eat herbs as food. Living is taking care of your body, doing exercise and taking care of your mind. When you are healthy, you will not become a burden on your family' (O-lunla, April 2017, p. 30).

It is noticeable that in this ending, linguistic strategies were used by claiming common fact techniques as 'truth' for old people. This claiming common fact is represented by words such as "older people" and "retired persons" for every old person as seen from above. "Older people", and "retired persons" in this excerpt were used to claim common fact—that having a lot of time and having 
declining health is true for all old people. Tips and suggestions from women, in this way, guide readers as to how to conduct themselves in specific situations regarding their health and mental well-being for the possible health benefits that women suggest in particular.

Additionally, there are tips and suggestions provided by the magazine for older adults at the bottom of the page about travelling tips for the elderly. These tips are shown only in the stories of older women accompanied by their sons or daughters travelling abroad together. These tips thus serve a particular purpose and are applied to both older women and their descendants. The endings in relation to travel tips are usually placed in different colorful textboxes and begin with the typical word "Tip." Illustrative examples are: 'Tip: if you buy travel insurance, you should tell family members before travelling' (O-lunla, August 2017, p. 10) and 'Tip: When travelling, you may prepare books or simple activities for elders in order to kill time while waiting for line and to deal with the long wait times' (O-lunla, August 2017, p. 11). These tips and suggestions are short and practical since they can be applied to the readers' real lives. The advantage is that the readers learn not only from the women's stories but also from the extra advice. In these, the endings are commonly travelling abroad tips for older adults. The ending, in this way, implies a positive portrayal of older age in terms of physical strength and good health.

Occasionally the stories end with advertising in the form of websites relevant to the women's businesses. Advertising women's work, such as artworks that are available to buy, underlines women's individuality, as displayed in the following example:

'She is not serious with profit taking. She does it because she knows the health benefits of quilting and would like to invite people over 6o years old who are still energetic to do hobbies regularly... If you would like to do quilting as she invites you to, why don't you try? Then, you will find your own potential. Please visit www.facebook/kawaibysuree' (O-lunla, June 2017, p. 16).

Ending the interview columns in this way highlights the person's individuality in the sense that making a quilt and getting it sold is a goal-directed action which may not happen to everyone, especially people in their older age. Moreover, it promotes a woman's competence as an artist by promoting her work.

Lastly, the use of rhetorical questions in the endings in the magazine for older adults is applied to make the point that ageing is pleasant. The definition of a rhetorical question, as Leigh (1994: 20) has stated, is "asking a question for the purpose of asserting or denying something obliquely". This was evidenced 
by the fact that readers were persuaded to imitate the women's choices of life as shown in the following example: 'Good music can change your life...Listen to granny Lin's desire, would you like to try to choose your own song to recharge your energy for this coming New Year? (O-lunla, January 2017, p. 17). In contrast to 'the purpose of asserting or denying', the rhetorical question in this example was asked to show that a 67-year-old granny, who is a singer at Hey Mom Bar, charged up her life by singing and listening to music. On the one hand, this woman's option was assigned to be an example for readers to follow since readers have to choose a song as the woman did. On the other hand, this reveals people aged 60 and over are never too old to do what they desire.

Overall, figures of speech were used in the interview columns to convey ideas of ageing in the magazine for older adults I analyzed. These linguistic strategies revealed the positive aspects of ageing and the elderly women usually had positive views towards it. One way in which ageing emerged as pleasant was in the context of discussing the portrayals of women in the magazine. I shall therefore now examine the portrayals of Thai women in the magazine for older adults in my study.

\section{The Portrayals of Thai Women in the Magazine for Older Adults: Roles of Women}

The data in the interview columns collected from O-lunla magazine depicted women's roles as housewives, wives, mothers, widows, daughters-in-law, daughters and grandmothers. These seven roles conform to the conventional idea of old-fashioned gender images since all of these roles in the Thai culture, apart from being a daughter, begin after getting married. Moreover, the magazine reinforces the roles of women as housewives by pointing out that women are defined as housewives from when they are born: 'When I got married I knew exactly that I was born as a housewife' (O-lunla, March 2017, p. 18). It is obvious that the magazine emphasizes the ideas of femininity by creating the concept of a "happy housewife," as stated by a housewife who had lost her husband: 'sometimes I did things alone. I told myself that I was so happy' $(O$ lunla, March 2017, p. 19). This allegory of the "happy housewife," according to Friedan (1992), became a prominent discourse of femininity from the 1950s to the 196os. However, it is still the case in 2017 as demonstrated in previous examples.

Considering the construction of women and the accompanying visual images in the interview columns, it is explicit that the magazines are therefore contrary in certain ways to feminism since they suggest conventional social norms for women. This is evident in women's roles as housewives and the idea 
that the woman's place is restricted to the domestic sphere. These social norms frame the idea of what roles are suitable for women and men in family units and that women are more likely to perform unpaid domestic work, such as cleaning and cooking.

A strong sense that the magazine for older adults domesticates women and supports male dominance is illustrated by the construction of womanhood in a hierarchy, in which women are inferior to men. This idea is supported by a metaphor used in the interview column: 'Sumalee Womgsawan, the wife of Rong-wind beneath an eagle's wings. Everybody calls her aunty Tim' (O-lunla, March 2017, p. 17). The woman in this metaphor is compared to wind that is beneath an eagle's wings. The eagle, in this sense, refers to the husband. Although this woman has a significant role in helping her husband to "fly" like an eagle, her ability is invisible like the wind. This is an example of how women as housewives are seen in terms of metaphorical concepts.

Another femininity convention depicted in the magazine for older adults in my sample is the notion that women's lives are fulfilled by being mothers. The construction of women as mothers is connected with decisions on particular issues. More than that, such decisions are based on the idea of putting children first and the woman dedicating herself to her children instead of pursuing further education or working. A typical example follows:

'In the past, although there were international scholarships offered to me, I did not go. If I had decided to accept the grants, I would not have had a chance to stay with my children. On the contrary, my friends got scholarships and they went to do further study abroad. When they came back, they got promoted at work. I chose my children, not the study. Therefore, I did my Master degree in Thailand' (O-lunla, April 2017, p. 29-30).

Motherhood here is consistent with liberal feminist views in the sense that it excludes women from public life. However, the notion of motherhood in the magazine for older adults I investigated is constructed as the fulfillment of a woman and a woman's devotion to mothering is the right decision since it does not create economic dependence on men. This is made evident by the fact that the portrayals of all elderly women having their own offspring are associated with paid jobs. This indicates that women are not only expected to be responsible for children and to be willing to sacrifice themselves for their children but also to fulfill their jobs in order to achieve career success.

By representing women as widows, the traditional belief of gender norms is also emphasized. To be more specific, women are expected to be in heterosexual relationships and stay monogamous after their husbands have 


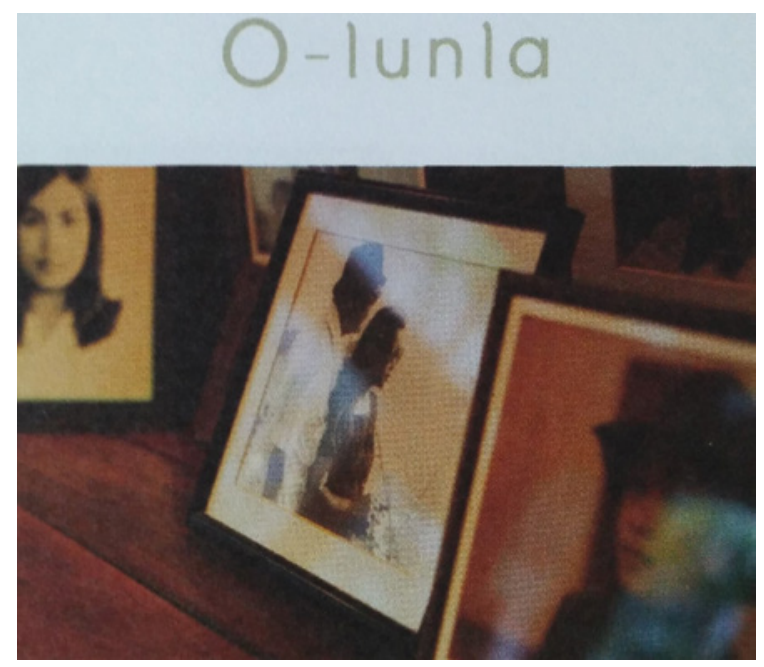

FIGURE 1 A photo of a woman together with her deceased husband (O-LUNLA, MARCH 2017, P. 17) SOURCE: AUTHOR'S PHOTOGRAPH

passed away since monogamous marriage focuses on a single relationship between couples and monogamous women, in the conventional belief, according to Buaphet (2014: 203), are viewed as the "ideal" in Thai society. Here is an example: '13 March 2009, he passed away. Every time I think about this, it makes me sad. People normally ask me whether I am lonely or not? Loneliness and remembrance are different. I am not lonely. I have a lot of things to do. But if you ask me whether I miss him or not? Yes, I do' (O-lunla, March 2017, p. 18). Her remembrance of her deceased husband was also proved by the photo displayed in the interview columns, as seen in Figure 1. In relation to the connection between the woman and her lifeless husband, a photo of the woman together with her husband is placed in the middle of the frame. The other two photos of the unsmiling woman are put not only to show what, apparently, she is (monogamous, sad) but also to display what, evidently, she is not (polygamous, happy), and in this sense, they are actually placed to affirm the love of her life.

As with the notion of widows, the representation of women as daughtersin-law connects women to conventional gender norms. Women are supposed to have monogamous relationships, respect their husbands and mothers-inlaw, and talk about them in positive ways, as shown in the statement below:

'My house is close to my mother-in-law's house. When he wants to eat something, he will tell me to ask his mother how to cook it...I would say 
that his mother is the first expert in my food. She is still alive and 105 years old. Although she is as not strong as before, she has a really good memory' (O-lunla, March 2017, p. 18).

Another role of women portrayed in the interview column is being daughters. The construction of women as daughters in the magazine for older adults in my sample was connected to having respect for their own mothers in the sense that their mothers are their role models. Moreover, this can strengthen the bond of their relationships even if their mothers have passed away as evident in the following examples: 'I now understand the significance of my mother. When she was alive, she did everything for our better lives. Although she passed away, she could still make me a better person. This is motherhood' (O-lunla, October 2017, p.12) and 'When I have problems, I think of my mother. In the past, I never listened to what she said. But when I was in trouble and thought back to what she had taught me, her words seemed to be very clear' (O-lunla, October 2017, p.12). Having respect for their mothers, as previously discussed, is depicted as essential for daughters because it conveys not only the idea of being a good daughter but also the notion of the type of mother that the daughters will become in the future. Daughters are influenced only by their mothers' teachings. The magazine reinforces the conventional idea of childcare - that women, not men, are expected to be responsible for it.

By depicting women as wives remarrying at an older age, the magazine suggests that monogamy is not necessarily considered as a prototype for women in Thai society and that women should not be restricted to having sexual relations with only one person. This norm presented by the magazine is in contrast to the culture of monogamy in traditional Thai cultural norms as previously discussed. Furthermore, this implies that ageing is not an obstacle to lovelove and relationships happen regardless of age, as can be seen in the following: ' 20 years ago, Aunty Sri fell in love again at the age of 57 with Dr. Chingchai Hanjaneluck, a business man, aged 55 . They have lived together as a couple since then' (O-lunla, September 2017, p. 19).

When it comes to discussing the depiction of women as grandmothers, the magazine challenges the negative perception of older adults as inactive and incompetent by connecting older women to new technology and demonstrating how they adjust and involve themselves with change. To put it another way, older women are portrayed in a positive way regardless of their physical limitations as seen in the following: 'Being a digital grandma is good. It helps me understand my grandchildren easily. It seems like we speak the same 


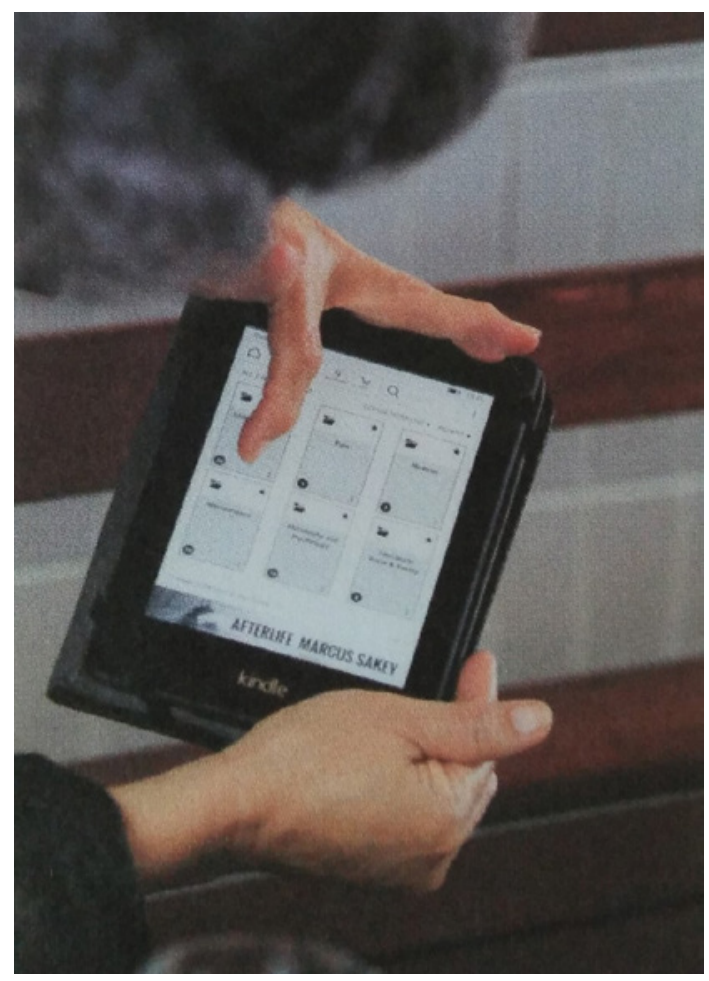

FIGURE 2 An older woman using a Kindle

(O-LUNLA, SEPTEMBER 2017, P. 19)

SOURCE: AUTHOR'S PHOTOGRAPH

language' (O-lunla, September 2017, p. 21); 'I have created a privacy setting for our Facebook group, namely 'Grandpa Grandma and Children. There are eight members in this group; six grandchildren, a grandfather and me. But grandpa has never shown up, the one who usually posts is me' (O-lunla, September 2017, p. 21); and 'I also have Kindle. It is very convenient. I can download many books to save them in specific categories' (O-lunla, September 2017, p. 21). The reconstitution of gender images in the magazine for older adults thus involves the interplay of modern choices and social expectations, as displayed in Figure 2.

In convergence culture, there are far more channels to read. Books are available to read in other ways: on computers, tablet computers, IPads, Kindles, etc. In Figure 2, the link between the old woman and the Kindle is made visually. The woman's grey hair and wrinkles on her fingers are iconic signs presented in order to connect this older woman to the Kindle through her touching its 
screen. Through this, the photo displays only her hair and hands instead of her face. This indicates that using Kindles or technological tools in old age can be applied to other older women, not only this woman in particular. Figure 2 thus suggests the positive values associated with technology.

6 The Portrayal of Thai Women in the Magazine for Older Adults:
Occupations for Women

A person's occupation is one of the criteria for defining the particular attributes in each society as feminine or masculine. According to Geert Hofstede (1980: 296), feminine societies are more likely to have explicit characteristics, such as the "belief in equality of the sexes; less occupational segregation (e.g. male nurses); men and women both being breadwinners and following the same type of higher education." Masculine societies, on the other hand, have different features: "belief in the inequality of the sexes; some occupations are considered typically male occupations, whereas other occupations are considered typically female; men are breadwinners, women are cake makers; men and women follow different types of higher level education" (Hofstede 1980: 297). Occupations in this context thus have connotations for the articulation of femininity in the magazine for older adults in my study. That is to say, the interview columns under study here depict women as economically active in various occupations. Table 2 demonstrates the sorts of occupations found in the magazine for older adults studied.

Table 2 shows that the occupations in the magazine for older adults were quite varied and were not lower middle-class jobs in particular. There were twelve occupations represented for the women in the magazine: singers, housewives, lecturers, business owners, Facebook page owners, writers, actresses, artists, chairpersons, cooks, radio presenters, and vice-chairpersons.

Considering the set of these occupations, apart from housewives, they are mostly in the public sphere and require specific skills and proficiency, such as lecturers, singers, actresses, cooks, artists, and writers, as can be seen in the following examples: 'This year she is 75 years old but her sweet voice is still charming. In 2016, Sweetnuch released her Tide Thai album' (O-lunla, January 2017, p. 13) and 'One day, granny Lin posted herself on Facebook while playing the guitar and singing Why do I love you so. With her appealing voice, her post became very popular online. There were people sharing and viewing this clip almost seven million times in a few days' (O-lunla, January 2017, p. 17). This also signifies the notion embedded in the magazine for older adults - that the women's sphere is not necessarily restricted to domesticity. This was also 
TABLE 2 Occupations for Women in Interview Columns: O-lunla, January-October 2017

Occupations

Total

$\begin{array}{lr}\text { 1. Singers } & 4 \\ \text { 2. Housewives } & 3 \\ \text { 3. Lecturers } & 3 \\ \text { 4. Business owners } & 2 \\ \text { 5. Facebook page owners } & 2 \\ \text { 6. Writers } & 2 \\ \text { 7. Actresses } & 1 \\ \text { 8. Artists } & 1 \\ \text { 9. Chairpersons } & 1 \\ \text { 10. Cooks } & 1 \\ \text { 11. Radio presenters } & 1 \\ \text { 12. Vice-chairpersons } & 1 \\ \text { Total } & 22\end{array}$

evident in the types of occupation displayed in the magazine and the fact that being a singer was the most common occupation, as shown in Table 2.

When the women were presented in the public sphere, the interview columns linked their occupations to their happiness, as illustrated in the following examples: 'I will do it until I do not have enough energy because it is my real happiness' (O-lunla, March 2017, p. 19) and 'I'm almost 80 years old. If you ask me why I work too much though I'm this old, it is because my parents taught me that work makes us happy' (O-lunla, February 2017, p. 21). Working beyond retirement age, in this sense, brings happiness into women's lives. The recognition of happiness is also emphasized in the photos of women doing their jobs in the public sphere with smiles on their faces portrayed in the interview columns.

Furthermore, this idea was affirmed by an overstatement used in the interview column to promote positive character traits of elderly women as happy and hardworking. The overstatements associated with dedication to work were applied to signify that ageing is not an obstacle to work and that women can work (hard) as long as they want, regardless of their age. Examples include the following: 'I will work as a teacher until I die' (O-lunla, October 2017, p. 8) and 'Teacher Lek has been working as a director of school almost 10 years. She spends 24 hours at school' (O-lunla, October 2017, p. 9). These two examples 
reveal overstatement as a language technique for highlighting devotion to work. The overstatements here convey the idea that working hard is desirable, especially for aged individuals. In addition, the statements imply that ageing does not hinder older people from working.

Additionally, the magazine reinforces the notion of working past retirement age by using paradox. Leigh (1994: 20) has defined paradox as "a statement that either seems to or actually does contradict itself." In the magazine for older adults, the use of paradox usually involves creating positive ideas of ageing. That is to say, ageing is not regarded as an obstacle to doing things in women's lives, as can be seen in the following: 'After 60 years old, most people reduce their work and would like to take a rest. Teacher Lek, on the contrary, has started following her new dream - small dream but big, because it is a job to 'create human' (O-lunla, October 2017, p. 9). The last sentence employs two opposite words (small and big), which contradict one another. The idea embedded in this paradoxical statement is that a small dream which can be made real has a big impact. Here, this 69-year-old woman's dream is to be a teacher, teaching students at her own school. This is contrary to the general expectation of older people - that the age of 60 and above in Thailand is the retirement age and it is a time when people should not continue to work. The concept of working after retirement age, in this way, emphasizes individuality in the sense that building one's own school and being a teacher are goal-directed actions that may not occur to every aged person.

In the magazine for older adults, even the idea of individuality is directly linked to one's work. This is evident in the use of claiming common fact for older adults in the interview columns. Another example is 'Old people want to sleep during the day. If I start teaching, however, I won't feel sleepy at all' (O-lunla, February 2017, p. 21). On the one hand, "old people" and "want" in this sentence signify that sleeping during the day is what all elderly people want to do. This implies that older adults are quite feeble. On the other hand, stating "If I start teaching, however, I won't feel sleepy at all" reinforces the idea that this woman who works as a teacher is different from other older people. Claiming common fact, in this sense, is used to differentiate the woman in the magazine from other elderly people in terms of having enough energy to work.

Moreover, the notion of working until old age is expressed through metaphor used in the interview columns. My thinking on metaphor is guided by George Lakoff's and Mark Johnson's, Metaphor We Live By (1980). The essence of metaphor, in agreement with Lakoff and Johnson (2003: 5), is "understanding and experiencing one kind of thing in terms of another." In the case of the interview columns in the magazine for older people, the findings show that 
metaphor is used to convey positive perceptions of older people. The metaphor in O-lunla magazine is used to describe life in old age as being similar to a big tree - OLD AGE IS A BIG TREE. A relevant instance is found in a 69-yearold woman's interview column: 'A big tree which is grown from a seed - if we plant its seed into soil - will begin to grow roots in soil. It has a history. Its roots hold land together and gradually grow. Then, the tree will bear fruit, overshadow and be useful' (O-lunla, October 2017, p. 11). The tree here, in fact, is not just a tree. It refers to an old adult. Furthermore, the process of growing a tree and the time it takes for the tree to bear fruit are similar to the person in old age who has experienced and gone through difficult times before he or she "shines." In other words, this metaphor signifies the notion of ageing - that the longer old people live, the more useful things they can do for society. This then might shape a systematic way of thinking about ageing in a positive way.

It is noticeable that the occupations such as Facebook page owner and radio presenter depicted in the magazines connect ageing to technology in a positive way. Embedded in this view is the presentation that ageing women can, in fact, have the ability to use technology effectively with pleasing results, as shown in the following examples: 'Next is to work as a radio presenter, I do it every week on FM 96.5 MHz - thinking radio. I am the oldest (laugh). I am happy to work here because I can talk about what I know to radio audiences' (O-lunla, February 2017, p. 21) and 'My son suggested that I make a Facebook page but he did not have the time to teach me. So I looked for someone who could help me and named the page as Kawai-I by Suree (www.facebook/kawaibysuree) which has been open for 4-5 months' (O-lunla, June 2017, p. 16).

Although the occupations presented in the magazine are mostly in the public sphere, they are quite highly gendered and to some extent related to the fields associated with women. Women are expected to fulfill stereotypically feminine jobs, such as teaching, acting, cooking, writing, instead of working in construction, for instance. Although the women are displayed in maledominated jobs - chairpersons and business owners - these women are still placed into more feminine specialties (yoga schools, restaurants, and hotels).

Unlike other occupations, being a housewife was the only unpaid domestic job portrayed in the magazine. In discussions surrounding housewives, however, the magazine for older adults studied depicted elderly women as senior travelers instead of homemakers. It was distinctive that these housewives were not restricted to the domestic sphere. These women's lives were fulfilled by descendants, not money. This was evident in all three stories presenting women as housewives - that they were directly linked to travelling abroad with their sons and daughters in place of staying at home. 
Although culturally, the expectation is still that women depend on men, in the magazine for older adults in the present study, men are marginalized, and changes in women's lives are not constructed as dependent on men because most of the women presented in the interview columns have their own paid jobs after retirement. The changes for women through men's support are thus not necessarily regarded as part of women's lives. On one level, this is an attempt to promote women's abilities, but on another level male dominance is also edited out.

\section{7}

\section{Conclusion}

The study of the images of Thai women in the magazine for older adults investigated here was designed to answer primary research questions about how ageing and Thai women are depicted in the magazine. The analysis of these interview columns in terms of their components, storylines, linguistic strategies and images indicates that happiness, work and health are three significant attributes in elderly women's lives. The meaning of "ageing," as demonstrated through linguistic strategies is interpreted in a positive way. The positive perspectives are directly linked to pleasant experiences and individual differences.

Although oldness, according to Bytheway (1995), Calasanti and Slevin (2001), and Holstein (2001), is connected to negative features such as sexlessness, unhealthiness, social unacceptance and physical unattractiveness, the magazine for older adults looked at here is more likely to represent oldness in different ways. In fact, the similarities between elderly celebrities and ordinary aged women associated with ageing appear to be common characteristics of women. By illustrating images of aged women as beautiful and happy, the ideology of femininity in the interview columns underlines beauty and happiness as key points in old age. Furthermore, the individual differences in the magazine for older adults are reinforced in the depiction of elderly women with a competency in technology and the ability to work in their older age. In this way, older age, like gender, is not a biological given but is socially constructed.

The stories present conventional femininity as formerly analyzed in the sense that the roles of women are considerably conventional and in relation to domesticity. All of the roles, apart from being a daughter, highlight women's status in connection to men, since they will be given to women after marriage. However, these stories also encourage women to strive to be better wives, housewives, mothers, widows, daughters, daughters-in-law and grandmothers. 
More specifically, contradictory norms are presented in the magazine for older adults to illustrate that women are not meant to be monogamous and monogamy is not necessarily regarded as an archetype for older women in Thai society. This is consistent with contemporary notions of femininity in Western culture in the sense that it is not seen as fixed but changes over time as a result of changing cultural values. As regards the depiction of women in the public sphere, older women are portrayed in various occupations with specific skills. This indicates that women in later life, after retirement, are constructed as economically independent and that they do not rely on men financially. The magazine for older adults thus frames particular views of ageing and images of Thai elderly women for the reader.

\section{References}

Amsuk, Ratchaphon. 2013. The Proposed Policy on Preparation for the Ageing Thai Population. Nakhom Pathom: Mahidol University.

Bell, Inge P. 1976. The Double Standard. In Growing Old in America, edited by B.B. Hess. New Brunswick, N.J.: Transaction Books.

Buaphet, Permtip. 2014. Readers' Real-life Narratives in Selected Contemporary Thai and UK Women's Magazines: A Comparative Study. Doctoral dissertation, University of York, UK.

Burgess, Ernest W. 1960. Ageing in Western Culture. In Ageing in Western Societies, edited by E.W. Burgess. Chicago: University of Chicago Press.

Butler, Robert N. 1969. Age-ism: Another Form of Bigotry. The Gerontologist 9.4: 243-6. Bytheway, Bill. 1995. Ageism. Buckingham: Open University Press.

Calasanti, Toni M. and Kathleen F. Slevin. 2001. Gender, Social Inequalities, and Aging. Oxford: Altamira Press.

Chaiyasin, Wijiga. 2004. The Identity of Competent Women in Women's Magazines between 1997-2002. Bangkok: Chulalongkorn University.

De Beauvoir, Simone. 1970. The Coming of Age. New York:W.W. Norton \& Company, Inc.

Fairclough, Norman. 2010. Critical Discourse Analysis: The Critical Study of Language. $2^{\text {nd }}$ edition. Harlow: Longman Group Limited.

Friedan, Betty.1992 [1963]. The Feminine Mystique. Harmondsworth: Penguin.

Hofstede, Geert. 1980. Culture's Consequences: International Differences in Work-Related Values. Beverly Hills: Sage.

Holstein, Martha. 2001. A Feminist Perspective on Anti-Aging Medicine. Generations 25.2: $38-43$.

Humm, Maggie. 1995. The Dictionary of Feminist Theory. $2^{\text {nd }}$ edition. New York: Ohio State University Press. 
Jitapunkul, Sutthichai and Napaporn Chayovan. 2001. National Policies on Ageing in Thailand. Bangkok: Chulalongkorn University.

Junwang, Worraruethai. 2015. Fall in Thai Persons. Bangkok: Chulalongkorn University. Kaikeaw, Sirinya. 2014. Needs for Assistance of the Thai Elderly Living Alone. Nakhom Pathom: Mahidol University.

Kessler, Eva-Marie, Katrin Rakoczy and Ursula M. Staudinger. 2004. The Portrayal of Older People in Prime Time Television Series: The Match with Gerontological Evidence. Ageing and Society 24.4: 531-552.

Knodel, John, Bussarawan Teerawichitchainan, Vipan Prachuabmoh and Wiraporn Pothisiri. 2015. The Situation of Thailand's Older Population: An Update based on the 2014 Survey of Older Persons in Thailand. University of Michigan: Population Studies Center.

Lakoff, George and Mark Johnson. 2003. Metaphors We Live By. Chicago: The University of Chicago Press.

Lee, Monica M., Brian Carpenter and Lawrence S. Meyers. 2007. Representations of Older Adults in Television Advertisements. Journal of Ageing Studies 21.1: 23-30.

Leigh, James H.1994. The Use of Figures of Speech in Print Ad Headlines. Journal of Advertising 23.2: 17-33.

Lumme-Sandt, Kirsi. 2011. Image of Ageing in a 50+ Magazine. Journal of Ageing Studies 25.1: $45^{-51 .}$

Maison, Kanokwan. 2001. The Power of Women's Negotiation through Body Presentation in Thai Magazines. Bangkok: Chulalongkorn University

Marshall, Leni. 2006. Ageing: A Feminist Issue. NWSA Journal 18.1: vii-xiii.

Nead, Lynda. 1988. Myths of Sexuality: Representations of Women in Victorian Britain. Oxford: Blackwell.

Nirannoot, Khian. 2003. The Perpetuation of Patriarchy through Women's Magazines. Bangkok: Chulalongkorn University.

Potharin, Danusorn. 2011. Factors Affecting Healthcare Expenditure of the Thai Elderly. Nakhom Pathom: Mahidol University.

Rose, Gillian. 2014. Visual Methodologies: An Introduction to Researching with Visual Materials. $3^{\text {rd }}$ edition. London: SAGE Publications Ltd.

Russell, Cherry. 1987. Ageing as a Feminist Issue. Women's Studies Int. Forum 10.2: $125^{-132 .}$

Saengchan, Thidsanu. 2014. Factors Associated with Knowledge of Caregivers among Elderly Thais. Bangkok: Chulalongkorn University.

Sanitya, Rugsapon. 2012. Factors Influencing Psychological Health of Thai Elderly Population. Bangkok: Chulalongkorn University.

Sontag, Susan. 1972. The Double Standard of Ageing. Saturday Review 23: 29-38. 
Supawan, Sarochpan and Chamaiporn Kanganakitsakul. 2014. The Social Construction of the Elderly Representations. Journal of Sociology 10.1: 93-136.

Suwannarada, Worawet, Siriphan Sasat and Supaporn Kumruangrit. 2010. Demand for Long-Term Care Services of the Elderly in Bangkok Metropolitan. Economics and Public Policy Journal 1.1: 20-41.

The National Committee for the Elderly. 2014. Situation of the Thai Elderly 2014. Bangkok: Foundation of Thai Gerontology Research and Development Institute (TGRI). United Nations (UN). 2015. World Population Prospects: The 2015 Revision, DVD Edition. Zhang, Yan Bing, Jake Harwood, Angie Williams, Virpi Ylänne-McEwen, Paul Mark, and Caja Thimm. 2006. The Portrayal of Older Adults in Advertising: A Cross-National Review.Journal of Language and Social Psychology 25.3: 264-282. 